\title{
Plaatjiegroeifaktore en wondgenesing
}

Waar die funksie van bloedplaatjies sedert die begin van die eeu aan hemostase of natuurlike bloedstelping gekoppel word, is die betrokkenheid van bloedplaatjies by wondgenesing minder bekend.

Dit het nou aan die lig gekom dat peptiedgroeifaktore 'n sleutelrol by wondgenesing speel. ${ }^{1.2,3}$ Groeifaktore wat tydens die bloedstollingsproses uit plaatjiegranules deur die kragtige plaatjie-agonis, trombien, vrygelaat word, stimuleer wondgenesing deur selverdeling, die sintese van sekere bestanddele van ekstrasellulêre grondstof, angiogenese of die groei van nuwe bloedvate, asook deur chemotakse van die inflammatoriese selle. Verskeie groeifaktore is reeds geïdentifiseer, nl. plaatjie-afkomstige groeifaktor (PAGF), plaatjie-afkomstige endoteelgroeifaktor (PAEFG), plaatjie-afkomstige angiogenese faktor (PAAF), fibroblast-groeifaktor (FGF), transformerende groeifaktor $-\beta$ (TGF- $\beta$ ) en 'n aantal outokriene en parakriene groeifaktore. ${ }^{4}$

Vertraagde wondgenesing is ' $n$ probleem van besondere geneeskundige belang. Waar genesing van velwonde gewoonlik geredelik vinnig plaasvind, is daar sekere toestande waar ulsera, ten spyte van doelgerigte optrede vir maande of selfs jare, voortsmeul (diabetes mellitus, porfirie, hiperkortisolisme, lupus erythematosus, bestraling en chemoterapie).

In die lig van die feit dat groeifaktore vrygelaat word wanneer trombien, 'n kragtige plaatjie-aktiveringsagonis, gedurende die stollingsproses gevorm word, is 'n plasmaplaatjie-trombienkonsentraat in die vorm van ' $n$ biologiese verband (hidrojel) ontwikkel vir gebruik by hardnekkige wonde van die vel. ${ }^{5}$ Behalwe dat trombien die plasmaplaatjiekonsentraat onmiddellik laat stol, het dit 'n bykomende voordeel, $\mathrm{nl}$. die onmiddellike vrylating van groeifaktore in die genesende jel. Hierdie behandeling met die plaatjiejel is reeds suksesvol aangewend waar vorige behandeling minimale of geen tekens van genesing getoon het nie. ${ }^{5.6}$ Epitelialisasie begin gewoonlik na 'n paar dae met bevredigende genesing daarna. ${ }^{\circ}$ Bemoedigende resultate met die lokale aanwending van plaatjiegroeifaktore by velwonde met vertraagde wondgenesing is reeds deur verskeie navorsers gerapporteer. ${ }^{5,6,7.8,9}$

Onlangs is daar ook vasgestel dat die mitogeniese effek van plaatjie-afkomstige groeifaktore op mensfibroblaste in selkultuur, afhanklik is van ' $n$ onbekende bestanddeel in sirkulerende plasma. ${ }^{6}$ Hierdie bevindings verleen verdere steun aan die opvatting van invloedryke navorsers wat 
reeds in die sewentigerjare vermoed het dat daar tenminste twee faktore in serum voorkom wat ' $n$ kardinale invloed op seldeling uitoefen, $\mathrm{nl}$. 'n hittestabiele, plaatjie-afkomstige groeifaktor wat tydens die stollingsproses deur bloedplaatjies vrygelaat word en 'n plasmafaktor wat die tempo van die toetrede van selle tot die $S$-fase van seldeling en dus ook DNA-sintese bevorder. ${ }^{10}$ Die sinergistiese effek tussen PAGF en insulien op fibroblastgroei is ook onlangs beskryf."

Verskeie aspekte van 'n grondliggende biologiese funksie wat wesenlike terapeutiese implikasies inhou, word tans in diepte nagevors.

\section{ENKELE WOORDVERKLARINGS}

Hemostase

Bloedplaatjies

Chemotakse

Fibroblaste

Trombien

Epitelialisasie

\section{Mitogenies}

\section{Serum}

DNA

Deoksiribonukleiensuur. DNA, die grootste molekuul in die sel is nou betrokke by selgroei, seldeling, oorerwing en proteïensintese.

\section{LITERATUUR VERWYSINGS}

1. Kohler, N. \& Lipton, A. (1974). Platelets as a source of fibroblast growth-promoting activity. Exp.Cell. Res., 87, 297-301.

2. Bowen-Pope,D.F. \& Ross,R. (1983). Is epidermal growth factor present in human blood?: alteration of EGF binding specificity in the radioreceptor assay, Biochem. Biophys. Res. Commun., $114,1036-1041$

3. Childs, C.B., Proper, J.A., Tucker, R.F \& Moses, H.L. (1982) Serum contains a plateletderived transforming growth factor, Proc. Natl. Acad. Sci. USA, 79, 5312-4316.

4. Hunt,T.K. \& La Van, F.B. (1989). Enhancement of wound healing by growth factors, N. Eng. J. Med., 321 (2), 111-112.

5. Franz, R.C. (1987). A new biological dressing for the promotion of wound healing, S.A. Med. J., 72, 810-811.

6. Franz, R.C., Van Wingerden, J. \& Bester, M. et al. (1993). Platelet growth factors and wound healing. The use of homologous platelet concentrate coagulum in the treatment of recalcitrant ulceration of the skin, Thromb. \& Haemos., 69 (6), 1613.

7. Brown, G.L., Nanney, L.B. \& Griffen, J. et al (1989). Enhancement of wound healing by topical treatment with epidermal growth factor, N. Eng. J. Med.,321 (2), 76-79.

8. Atri, S.C., Misra, J. \& Bisht, D. et al. (1989). Use of homologous platelet factors in achieving total healing of recalcitrant skin ulcers, Surgery, 108 (3), 508-512.

9. Knighton, D.R., Ciresi, K.\& Fiegel, V.D. et al. (1990). Stimulation of repair in chronic, nonhealing, cutaneous ulcers using platelet-derived wound healing formula, Surgery, Gynecology \& Obstet., 170,56-60.

10. Pledger, W.J., Stiles, C.D., Antoniades, H.N. \& Scher, C.D. (1978). An ordered sequence of events is required before BALB/ c-3T3 cells become committed to DNA synthesis, Proc. Natl. Acad. Sci. USA, 75 (6), 28349-2843

11. Pledger,W.J., Gardner,R.M.\& Epstein, P.M. et al. (1979. Cell cycle traverse and macromolecular synthesis in BHK fibroblasts as affected by insulin, Exp. Cell. Res., 118, 299-394.

\section{R.C. FRANZ}

Dept. Chirurgie, Fakulteit Geneeskunde, Universiteit van Pretoria, Posbus 667, Pretoria, 0001. 